\title{
First Record of Keeled Plump Bush-Cricket (Isophya costata Brunner von Wattenwyl, 1878) (Orthoptera, Tettigoniidae) in Slovakia
}

\author{
Soňa NUHLÍČKOVÁ ${ }^{1, *}$, Ján SVETLÍK ${ }^{1}$, Anton KRIŠTÍN²
}

\author{
'Staničná 318/19, 90066 Vysoká pri Morave, Slovakia. \\ ${ }^{2}$ Institute of Forest Ecology, Slovak Academy of Science, L'udovíta Štúra 2, 96053 Zvolen, Slovakia. \\ *corresponding author, e-mail: sonanuhlickova@gmail.com
}

Received: September 1, 2017; Accepted: October 16, 2017; Available online: December 29, 2017; Printed: December 31, 2017

\begin{abstract}
Keeled Plump Bush-cricket Isophya costata is one of ten orthopteran species of European Community interest (Annex II and IV of Habitats Directive), endemic to the Pannonian Basin in Central Europe. It was discovered for the first time in Slovakia in June 2017, in southwestern area of the country (the site Devínske jazero, $48.2722^{\circ} \mathrm{N} / 16.9404^{\circ} \mathrm{E}, 134 \mathrm{~m}$ a.s.l.), in continental flooded meadows. The presence of the species in this new site is copying the northern edge of its area. New data of species distribution, its habitat, accompanying orthopteran species are described and main threats and conservation measures of the species are discussed.
\end{abstract}

Key words: Orthoptera, distribution, habitat, conservation, Central Europe

\section{INTRODUCTION}

Comprising around 90 species, genus Isophya is one of the richest bush-cricket genera in the Palaearctic. There are nine Isophya species known in Slovakia till now (Krištín \& Kaňuch, 2017).

Keeled Plump Bush-cricket Isophya costata is an endemic species of the Pannonian Basin with low dispersal abilities and lives on lower altitudes. Its range is relatively small, fragmented and restricted to the Central and Eastern Europe. Occurrence of the species was confirmed in eastern Austria, western Romania, northern Serbia and Hungary (see fig. 1.; Harz, 1969; Berg et al., 1996; Heller et al., 2004; Chobanov et al., 2016).

In Austria, the population of I. costata reaches the north-western edge of its distribution and it is known only in the eastern part of the country (Viennese Basin) (Berg et al., 1996; Bieringer, 2009). The major part of the population is located south of the Danube River, from the eastern edge of the Alps via the Viennese Basin and Leitha Mountains to the Neusiedl Lake. To the north of the Danube data on the species are poorly marked. Most occurrences are situated in Lower March floodplains (Berg et al., 1996; Nagy et al., 2003; Bieringer, 2009).

In Romania, the species population reaches the eastern edge of its distribution. I. costata occurs in south-western Transylvania and along Mureș valley towards Hungary. The easternmost occurrence of the species was recorded near Sibiu, while the westernmost findings were located near towns Arad and Timişoara (Iorgu et al., 2008; Iorgu, in litt.).

The southern edge of the species' distribution was discovered between the Danube and the Tisza rivers, in the Subotica-Horgos sandy region, in northern Serbia. 


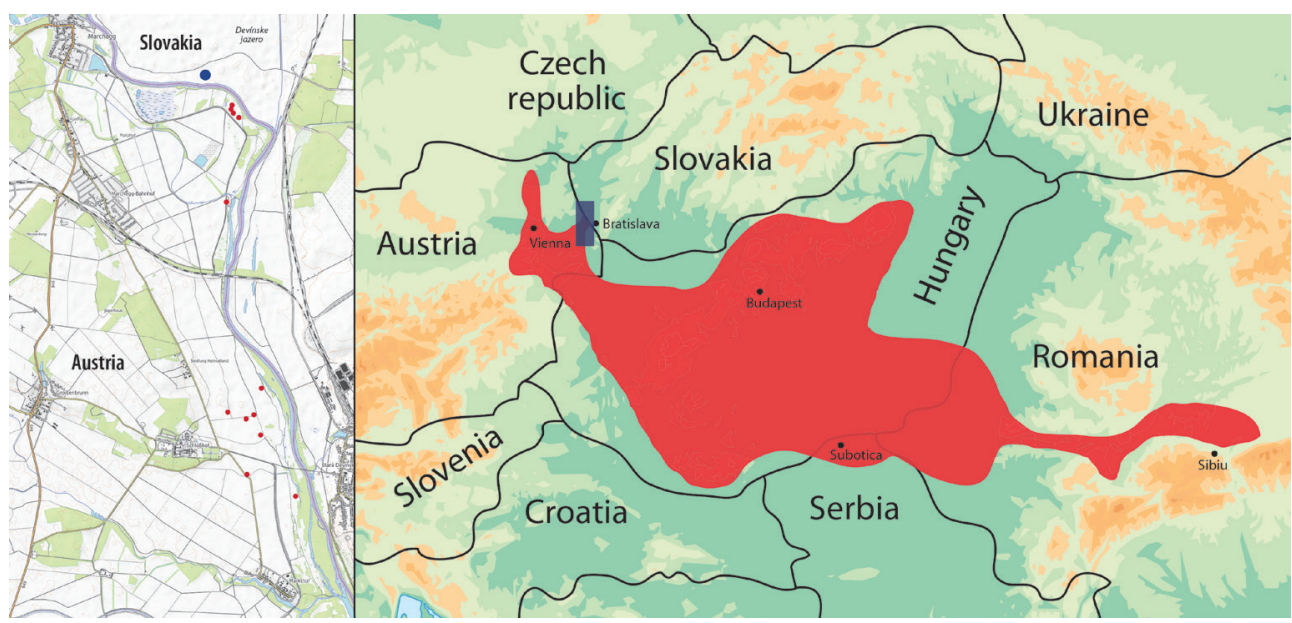

Fig. 1 - Records of I. costata in western Slovakia (blue dot) and in Austrian floodplain area (Lower Austria, red dots); the Morava River forms national boundaries of Slovakia and Austria (Source: Archiv ARGE Heuschrecken Österreichs) (on the left). Range map of the species in Europe (ex Chobanov et al., 2016) (on the right).

The population of Serbia survives in small, isolated patches rich in humid peat meadows, in Vojvodina (Szövényi \& Szekeres, 2011; Ivkovič, in litt.).

In Hungary, it is located the centre of the I. costata population. During the last decade, some large subpopulations have been discovered in the Hungarian Plain (Kiskunság National Park area, between the Danube and the Tisza rivers). Some of them occur on hundreds of hectares of continuous suitable grassland habitats. According to rough estimations, the overall size of these subpopulations exceeds 100,000 specimens, what could be among the largest known populations of the $I$. costata (Chobanov et al., 2016). Besides these, the other findings were in lowland areas (e.g. in inundation areas and on dams along the rivers) of the Körös-Maros NP district, located on the southeast part of the Great Hungarian Plain (Kisbenedek et al., 2009) and then also in Tolnai-Hegyhát district (S Hungary) (Kenyeres \& Bauer, unpub. ex Bauer \& Kenyeres, 2006). In addition, the species has several isolated occurrences also in the colline region of the Villányi and the Mecsek Mts (SW Hungary; Vadkerti et al., 2003; Vadkerti \& Szövényi, 2005) and in South-Baranya Hills (S Hungary; Transdanubian region; Vadkerti, 2004; Bauer \& Kenyeres, 2006). Other occurrences of the species can be found in the Balaton Uplands and on the southern slopes of the Transdanubian Mountains (Bauer \& Kenyeres, 2006). Finally, in regard to Slovak territory and boundaries, the northernmost occurrence of I. costata population in Hungary is known in the Cserhát hills (N Hungary; surroundings of towns Buják and Jobbágyi) (Szövényi et al., 2013) and in Pilis Mts. (Chobanov et al., 2016).

In Slovakia, the occurrence of the $I$. costata was unknown till now, in spite of several studies from areas neighbouring to its occurrence in eastern Austria and northern Hungary (Gavlas, 2003; Krištín et al., 2004; Krištín et al., 2005; Krištín \& Kan̆uch, 2017). However, in regard to findings in neighbouring countries (eastern Austria and Hungary), the species was likely to occur in southern and western part of Slovakia (Kočárek et al., 2005). Based on these studies, we hypothesized that the species occurs also in Slovakia, where we registered a small population in June 2017. 
Now we comment these new data of species occurrence, describe its habitat and discuss main threats and future conservation options within conditions of Slovakia.

\section{MATERIAL AND METHODS}

All specimens were found by sweeping-net, by searching of individuals and by acoustic detection of male calling song. For the acoustic analysis, several individuals were collected alive and recorded in laboratory conditions $\left(26^{\circ} \mathrm{C} ; 60 \%\right.$ humidity), using the digital recorder OLYMPUS DM-650. Resulting wave sound files were analysed with Adobe Soundbooth software (Fig. 2). Analysis of the habitat vegetation structure was made by Braun-Blanquet approach (Whittaker, 1962).

\section{RESULTS}

\section{Faunistical data of the species and its documentation}

The first record of Keeled Plump Bush-cricket was found on the $12^{\text {th }}$ of June 2017, in Devínske jazero, Záhorie lowland, West Pannonian Basin $\left(48.2722^{\circ} \mathrm{N} /\right.$ $16.9404^{\circ} \mathrm{E} ; 134 \mathrm{~m}$ a.s.l.). The site is located in the floodplain area of the Morava River between the villages Vysoká pri Morave and Devínska Nová Ves (Fig. 1; on the left). The first finding of the species was based on acoustic determination of a male calling song, which was subsequently verified in laboratory conditions (Fig. 2). According to Heller et al. (2004), morphological assessment of the species confirmed the presence of broad fastigium (broader than or as broad as scapus) (Fig. 3).

Consequently, using the sweeping method, we found four males and seven females in the site. We estimated the overall population size on 10-15 singing males on 1.5 ha (total study plot, measured as a convex polygon of the most distant points of found individuals in suitable habitat).

\section{Site description}

The I. costata specimens occurred in small, restricted area covered with tall standing grass and a great portion of herbaceous plants. The area represents a dry type of continental flooded meadows in Slovakia (Janišová et al., 2007). During the spring period, the Devínske jazero site is usually flooded twice - first as the result of high water level of Morava River and then also as the result of high discharges in the Danube River. The vegetation of the area belongs to the most dominant and species rich vegetation types in the Morava River floodplain (the Cnidio dubii-Deschampsietum ceaspitosae alliance) (Šeffer \& Stanová, 1999; Janišová et al., 2007). Altogether, 43 herb species were found in the discovered site of I. costata. Characteristic herbal species include e.g. Clematis integrifolia, Gratiola officinalis, Sanguisorba minor, S. officinalis and Serratula tinctoria. Drier areas were indicated by the presence of e.g. Jacea pratensis, Lathyrus pratensis, L. tuberosus and Leucanthemum vulgare.

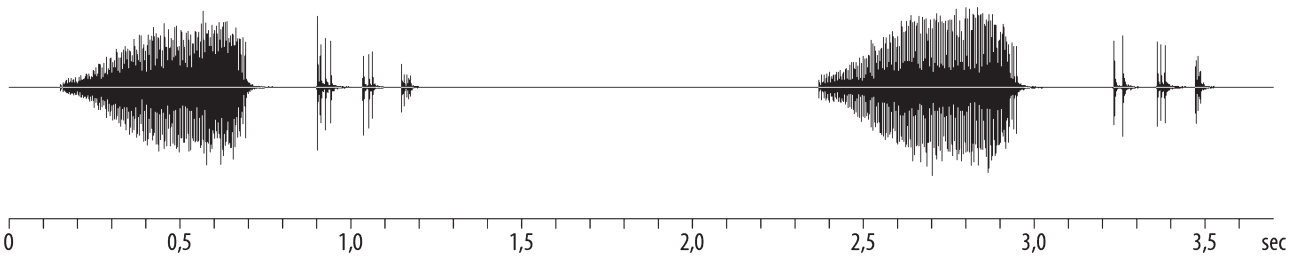

Fig. 2 - Oscilogram of male calling song (at $26^{\circ} \mathrm{C} ; 60 \%$ humidity). 


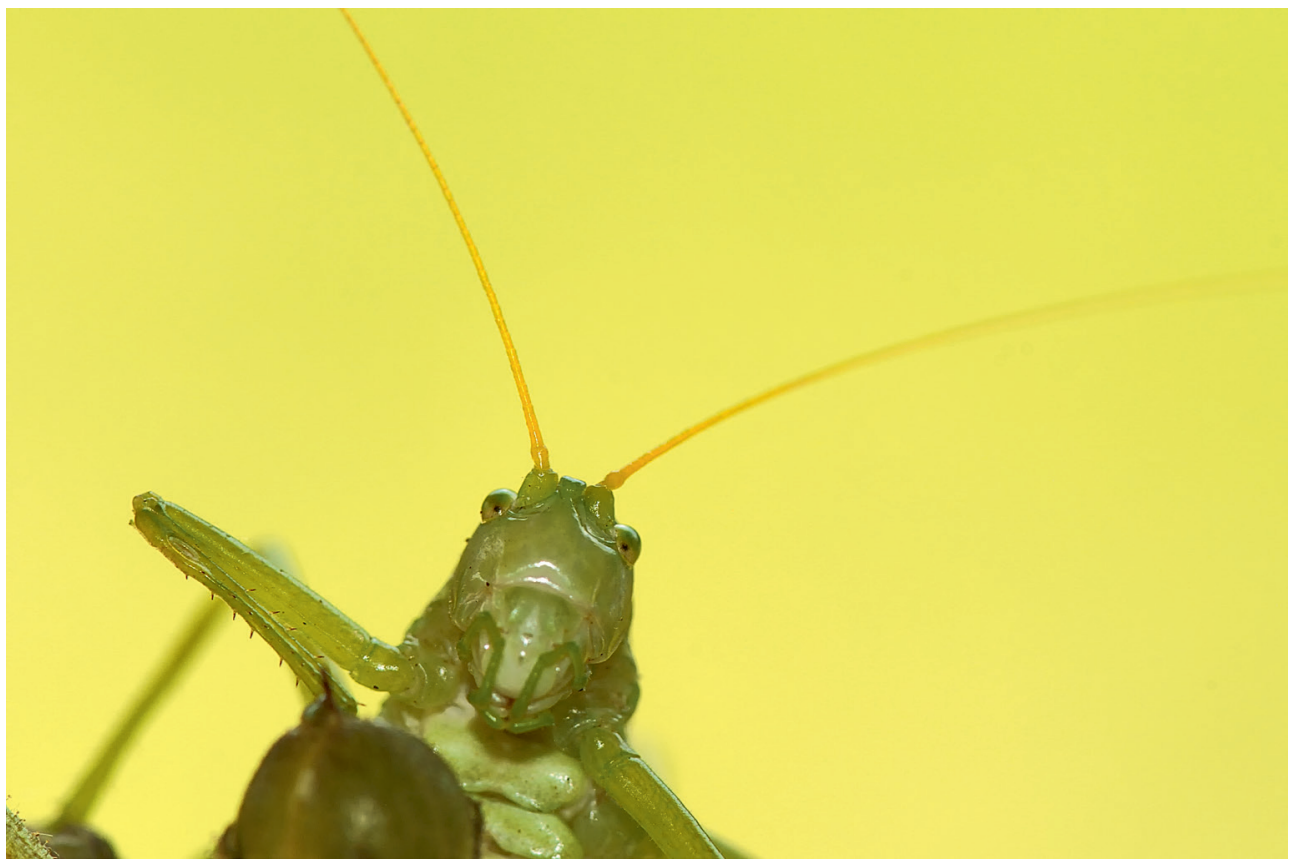

Fig. 3 - Detailed view on the broad fastigium of I. costata. Photo: Ján Svetlík.

Depending on floods, meadows of Devínske jazero are mowed twice a year (in May/ June and then in September/October).

In total, 18 orthopteran species (5 Ensifera, 13 Caelifera) were found in the study site. Conocephalus fuscus, Ruspolia nitidula, Metrioptera roeselii, Mecostethus parapleurus, Chorthippus albomarginatus and "Chorthippus oschei" were the most dominant and frequent species (these males had typical colour patterns of Ch. oschei: dark or black hind knees and white hind tarsi, but we can not exclude also the presence of hybrids. The hybrid zone between the two species might also exist in the study area; for more details, see e.g. Vedenina et al., 2009). The grasshoppers Stethophyma grossum and Pseudochorthippus montanus were less frequent species in the study plot.

\section{DISCUSSION}

The first map of the I. costata range was published in Red List of European Orthoptera (Chobanov et al., 2016) showing its recent known range (Fig. 1; on the right). First record of I. costata in SW Slovakia widened this knowledge and here we described its population size, when 10-15 singing males were located on the plot of 1.5 ha. The nearest known population of I. costata is located in Austria, in the floodplain area near the town Marchegg. One Austrian finding site is situated almost directly on the other side of the Morava River, about $1000 \mathrm{~m}$ from the first Slovak site record. Considering other findings in neighbouring countries, its occurrence is likely in suitable habitats of western and southern part of Slovakia closed to Hungarian border (Fig. 1).

In the future, there is a need for the further ecological research along the northern border of the range, especially in order to ensure the species and habitat 
protection. In Europe, the Keeled Plump Bush-cricket is listed in the Appendix II and IV of the Habitats Directive (www.europa.eu). According to IUCN Red List of Threatened Species I. costata is listed as Least Concern (LC) with the declining population trend (Chobanov et al., 2016). An attention will be focused on the species distribution in suitable habitats in western and southern part of Slovakia. Compared to other Isophya species, I. costata belongs to bush-crickets with broadest range of habitat types, from moist meadows to meso-xeric and xeric habitats (Vadkerti, 2004; Vadkerti \& Szövényi, 2005; Bieringer, 2009), rich in dicotyledonous plants that satisfy the food requirements of the species (Berg et al., 1996; Bauer \& Kenyeres, 2006; Bieringer, 2009; Szövényi \& Szekeres, 2011). Although the vegetation of described Slovak site is considered to be the most dominant and species-rich vegetation type in the Morava River floodplain (Šeffer \& Stanová, 1999; Janišová et al., 2007), our I. costata population was restricted only in small patches rich in herbaceous plants (e.g. Clematis integrifolia, Galium verum, Sanguisorba officinalis).

In general, Isophya species have a particular importance in the Carpathian Basin from the perspective of biogeography and habitat conservation. Due to the reduced movement ability (brachyptery), fragmented and isolated populations of low density and its close habitat-dependence, Isophya species very sensitively react to the habitat change (Bauer \& Kenyeres, 2006). Thus, based on a bioindication potential of orthopterous insects (Gavlas, 2003; Bauer \& Kenyeres, 2006; Kočárek, 2015), we expect that our future findings will be restricted in habitats of high ecological value.

In terms of species and habitat conservation, the serious threats to our population are early mowing and habitat loss due to expansion of invasive and ruderal plants (mainly Calamagrostis sp., Elytrigia repens, Cirsium sp. and Aster sp.). With respect to early development of I. costata, especially the occurrence of larvae stages in early April and adults in May and in order to preserve this animal, it will be essential to avoid mowing before egg laying (e.g. Bauer \& Kenyeres, 2006). In regard to inconspicuous behaviour (females and non-singing males), it often happens that these insects can be easily overlooked and thus disappear before they are discovered (e.g. Berg et al., 1996). In our case, the finding place was mowed two days after the population was discovered. Due to a lack and continuing loss of suitable habitat, early mowing and limited dispersal ability, we suppose that I. costata is highly threatened in Slovakia. We believe that new data on distributional patterns can provide appropriate protection of the species along the northern border of its area.

\section{ACKNOWLEDGEMENTS}

We would like to thank B. Kabinová for identification of the vegetation structure in the study site, I. Iorgu for important notes to the distribution of I. costata in Romania and T. Zuna-Kratky for maps, publications and important notes on the distribution of I. costata in Austria that helped us in our study.

\section{REFERENCES}

BAUER, N., Z. KENYERES (2006) Habitat preference studies of some species of the genus Isophya Brunner von Wattenwyl, 1878 (Orthoptera: Phaneropteridae) in the western part of the Carpathian Basin. Journal of Orthoptera Research, 15 (2): 175-185.

BERG, H.-M., G. BIERINGER, N. SAUBERER, T. ZUNA-KRATKY (1996) Verbreitung und Ökologie der Großen Plumpschrecke (Isophya costata BRUNNER V. WATTENWYL, 1878) an ihrem westlichen Arealrand (Österreich). Articulata, 11 (2): 33-45. (in German)

BIERINGER, G. (2009) Breitstirnige Plumpschrecke Isophya costata Brunner von Wattenwyl, 1878. In: Zuna-Kratky, T., E. Karner-Ranner, E. Lederer, B. Braun, H.-M. Berg, M. Denner, G. Bieringer, A. Ranner, L. Zechner (eds): Verbreitungsatlas der Heuschrecken und Fangschrecken Österreichs. Verlag Naturhistorisches Museum Wien: 76-77. (in German) 
CHOBANOV, D., P., A. HOCHKIRCH, I. IORGU, S. IVKOVIC, A. KRIŠTÍN, M. LEMONNIERDARCEMONT, T. PUSHKAR, D. SIRIN, J. SKEJO, G. SZÖVÉNYI, V. VEDENINA, L. P. M. WILLEMSE (2016) Isophya costata. The IUCN Red List of Threatened Species 2016: e.T44709818A70268719.

GAVLAS, V. (2003) Rovnokrídlovce (Ensifera, Caelifera) a modlivky (Mantodea) rôzne využívaných nelesných biotopov [Orthopteran (Ensifera, Caelifera) and Mantid (Mantodea) Communities in Variously Utilised Grassland Habitats (A Case Study from SW Slovakia)]. Vedecké štúdie, Vydavatel'stvo Technickej univerzity, Zvolen: $131 \mathrm{pp}$. (in Slovak)

HARZ, K. (1969) Die Orthopteren Europas. Vol. 1., Verlag Dr. W. Junk, Hague: 749 pp. (in German)

HELLER, K.-G., K. M. ORCI, G. GREIN, S. INGRISCH (2004) The Isophya species of Central and Western Europe (Orthoptera: Tettigonioidea: Phaneropteridae). Tijdschrift voor Entomologie, 147: 237-258.

IORGU, I., E. PISICĂ, L. PĂIŞ, G. LUPU, C. IUŞAN (2008) Checklist of Romanian Orthoptera (Insecta) and their Distribution by Eco-Regions. Travaux du Muséum National d'Histoire Naturelle "Grigore Antipa", 51: 119-135.

JANIŠOVÁ, M., P. HÁJKOVÁ, K. HEGEDÜŠOVÁ (eds) (2007) Travinnobylinná vegetácia Slovenska. Elektronický expertný systém na identifikáciu syntaxónov, Botanický ústav SAV, Bratislava: 263 pp. (in Slovak)

KISBENEDEK, T., T. DANYIK, E. VADKERTI (2009) A magyar tarsza (Isophya costata) és a Stys tarsza (I. stysi) populációk állapota és eloszlása a Körös-Maros Nemzeti Park Igazgatóság müködési területén Kisbenedek. Crisicum, 6: 185-198. (in Hungarian)

KOČÁREK, P. (2015) Druhová ochrana a bioindikační vlastnosti rovnokř́ídlého hmyzu. In: Biologie, ekologie a fylogeneze rovnokř́ídlého hmyzu (Orthoptera) a škvorů (Dermaptera). Univerzita Palackého v Olomouci, Přírodovědecká fakulta, Ostrava: 5-9. (in Czech)

KOČÁREK, P., J. HOLUŠA, L. VIDLIČKA (2005) Blattaria, Mantodea, Orthoptera \& Dermaptera of the Czech and Slovak Republics. Kabourek, Zlín: 349 pp.

KRIŠTÍN, A., P. KAŇUCH (eds) (2017) http://www.orthoptera.sk

KRIŠTÍN, A., P. KAŇUCH, P. PUCHALA (2005) Rovnokrídlovce (Orthoptera s.1.) Malých Karpát. Ochrana prírody, 24: 141-152. (in Slovak)

KRIŠTÍN, A., P. KAŇUCH, M. SÁROSSY (2004) Grasshoppers and crickets (Orthoptera) and mantids (Mantodea) of sand dunes in the Danube lowland (S Slovakia). Linzer Biologische Beiträge, 36: 273-286.

NAGY, B., K.-G. HELLER, K. M. ORCI, G. SZÖVÉNYI (2003) Neue Daten zum Vorkommen von Isophya-Arten (Orthoptera: Tettigonioidea) im östlichen Alpenvorland. Journal of the Swiss Entomological Society, 76: 161-172. (in German)

ŠEFFER, J., V. STANOVÁ (eds) (1999) Morava River Floodplain Meadows - Importance, Restoration and Management. DAPHNE - Centre for Applied Ecology, Bratislava: $187 \mathrm{pp}$.

SZÖVÉNYI, G., O. SZEKERES (2011) First record of Isophya costata in Serbia (Orthoptera: Phaneropteridae). Folia Entomologica Hungarica, 72: 5-7.

SZÖVÉNYI, G., K. HARMOS, B. NAGY (2013) The Orthoptera fauna of Cserhát Hills and its surroundings (North Hungary). Articulata, 28 (1/2): 69-90.

VADKERTI, E. (2004) Isophya (Orthoptera) fauna of South-Baranya-Hills (South-Hungary, Transdanubian region). Somogyi Múzeumok Közleményei, 16: 325-328.

VADKERTI, E., G. SZÖVÉNYI (2005) Habitat preference of four protected bush-cricket species (Orthoptera, Phaneropteridae, Isophya) in South Hungary. Biologia, 60 (5): 545-549.

VADKERTI, E., G. SZÖVÉNYI, D. PURGER (2003) The Isophya fauna of Mecsek and Villány Hills, SW Hungary (Insecta: Orthoptera). Folia comloensis, 12: 73-78.

VEDENINA, V., J. HOLUŠA, P. KOČÁREK (2009) The Chorthippus albomarginatus-group (Orthoptera: Acrididae: Gomphocerinae) in the Carphatian Basin: traces of hybridization between $C$. albomarginatus and C. oshei in southern Slovakia. Acta Zoologica Academiae Scientiarum Hungaricae, 55: 283-291.

WHITTAKER, H. R. (1962) Classification of natural communities. The Botanical Review, 28: 1-239. EUROPEAN UNION (1922) Annex II

*** Habitats Directive Appendix/Anex II ans IV (www.europe.eu) 